Türk Coğrafya Dergisi
Sayı 62: 29-37, istanbul
http://www.tcd.org.tr

Hakemli Makale

Reviwed Article

\title{
Enerji diplomasisi açısından siyasallaşan mekân, Hazar: Statü ve paylaşım sorunu
}

\author{
Politicized space in terms of energy diplomacy, Caspian: Problem of statue and allocation
}

\section{Taşkın DENiz*}

- Karabük Üniversitesi, Edebiyat Fakültesi, Coğrafya Bölümü

Geliş/Received: 07.11.2013 Kabul /Accepted: 20.03.2014

Sorumlu yazar/Corresponding author (T. DENiz) taskindeniz@karabuk.edu.tr

\begin{abstract}
Öz
Hazar Havzası, petrolün ilk bulunduğu yerlerden biri olup 20. Yüzyıldan itibaren önemli bir petrol merkezine dönüşmüştür. Bakü'den çıkartılan petroller onlarca yıl gerek Rusya gerekse de SSCB'deki tüm petrol üretiminin büyük kısmını karşılamıştır. Ancak SSCB sonrasında Hazara kıyıdaş ülke sayısının artması, Hazarın statüsü ve paylaşımı sorununu gündeme getirmiştir. Kıyıdaş beş devlet, ulusal ve uluslararası çıkarları doğrultusunda hareket etmeleri nedeniyle henüz statü ve paylaşım konusunda ortak karara varamamıştır. Hazar'ın statüsü, küresel güçleri ve enerji projelerini yakından ilgilendirmektedir. AB, alternatif kaynaklar bulmak için bölgenin kaynaklarını önemsemektedir. Rusya, enerji oyununda geriye düşmemek için bir taraftan Hazar'daki çıkarlarının ve doğalgaz satışının olumsuz etkilenmemesi, diğer taraftan Batılı şirketlerin bölgede etkin olmaması için çabalamaktadır. ABD, Hazar Havzası'nda Rusya egemenliğini kırmak için uğraşmaktadır. Türkiye ise, petrol ve doğal gaz boru hatlarının uluslar arası piyasalara arzında stratejik konuma sahip olmasının verdiği avantajları kullanarak, bölgedeki nüfuzunu artırmak istemektedir. Hazar, sahip olduğu özellikleri ile enerji diplomasisi açısından uluslar arası rekabeti ısıtan ve adeta emperyalist güçleri yeniden harekete geçiren bir mekân olarak ön planda kalmaya devam etmektedir. Anahtar Kelimeler: Enerji Diplomasisi, Hazar, Rusya, Azerbaycan, Türkiye.
\end{abstract}

\begin{abstract}
Caspian Basin, which is one of the first oil existing places, has turned into an important oil center since 19th century. Oils of Baku have provided to most of oil production tens of years in both Russia and USSR. But, after USSR, the problem of the Caspian's status and sharing has emerged due to increasing of the country number which has a border to the Caspian shore. Five of those governments could not compromise about status and sharing yet, because of their attitudes on the way of national and international profits. Global powers and energy projects concerns closely with status of the Caspian. EU cares about the region's sources in order to find alternative sources. Russia tries not to stay behind in energy game, not to be impressed negatively of natural gas sale of the profits in Caspian, and not to be effective of Western companies in the region. USA tries to dissolve Russia's domination in Caspian Basin. As to Turkey demands to increase the influence in the region by using the advantages it's strategic location in international markets offer of oil and natural gas pipelines. Caspian together with its features continues to come into prominence as a place that warms up international competition in terms of energy diplomacy and where set in motion to imperialist powers again. Keywords: Energy Diplomacy, Caspian, Russia, Azerbaijan, Turkey.
\end{abstract}

\section{Giriş}

İnsan yaşamının vazgeçilmez unsurlarından ve sürdürülebilir kalkınmanın en önemli araçlarından biri, enerjidir. Yüzyıllar boyunca temel enerji olarak insan ve hayvan gücü kullanılmıştır. 18. yüzyılda gerçekleşen sanayi devrimi ile birlikte insan ve hayvan gücünün yerini önce kömür ve sonrasında 19. yüzyıldan itibaren teknolojik araç ve gereçlere çalışma imkânı veren iki stratejik kaynak almıştır: Petrol ve Doğalgaz. 20. yüzyıldan itibaren sanayinin her alanında petrolün kullanılması ve petrole duyulan ihtiyacın artması, petrolü stratejik enerji kaynağı yapmıştır. Aynı zamanda petrol sahalarına yönelik siyasi, askeri ve ekonomik girişimler ile petrole kesintisiz ulaşabilme (enerji güvenliği) isteği de, devletleri karşı karşıya getiren temel politik bir soruna dönüştürmüştür. Böylece, yaklaşık 100 yıl 
önce, devletlerarası ilişkilerde çok önemli rol oynayan enerji diplomasisi (energy diplomacy) ortaya çıkmıştır. Bir devlet ya da küresel ölçekli bir şirketin, enerji kaynakları ile enerji pazarı arasında çıkarları doğrultusunda sergilediği düşünce ve davranışların tümü olarak ifade edebileceğimiz enerji diplomasisi, uluslararası siyasette önemli bir kavrama dönüşmüştür. Enerji diplomasisi, karmaşık ilişkiler ağını yansıtan uzun süreli politikaları kapsar.

Enerji diplomasi açısından önem taşıyan devletlerin bir kısmı küresel siyaset açısından ön planda olmayabilir. Örneğin Irak ve Kuveyt, küresel siyasette pek etkin durumda değiller ancak enerji diplomasi açısından önemlidirler. Enerji diplomasisinde uluslararası konjonktüre göre geleceğe yönelik planlar ve senaryoların yazılarak uygulanması önem taşır. Ayrıca enerji diplomasisi, enerji kaynaklarına sahip devletler ile pazar devletleri arasında bir baskı unsuru ya da silahı olarak kullanılabilmektedir. Örneğin Rusya, doğalgaz kaynaklarını $A B$ başta olmak üzere Ukrayna ve Türkiye gibi bölge ülkeleri üzerinde enerji diplomasisi açısından bir baskı aracı olarak kullanmaktadır.

\section{VERI ve YÖNTEM}

Araştırma konusuyla ilgili yerli ve yabancı literatür çalışması yapılmış, sayısal veriler konu ile ilgili resmi kurumlardan, bu kurumlara ait yayımlardan ve internet sitelerinden temin edilmiştir. Araştırma konusu ve ortaya konan bulgular açısından değerlendirildiğinde, araştırmanın siyasi coğrafya ve uluslararası ilişkiler başta olmak üzere konu ile ilgili sosyal bilimler literatürüne kaynaklık edeceği ve konuya ilişkin fikirlere yön verebileceği umut edilmektedir.

\section{ENERJi DIPLOMASISINDE GÜNÜMÜZ KOŞULLARI}

I. Dünya Savaşı sonrası İngiltere'nin Orta Doğu ülkelerine yerleşmesi, II. Dünya Savaşı'ndan sonra başlayan Soğuk Savaş Dönemi, 1950'li yıllarda ortaya çıkan milliyetçilik akımlarına bağlı olarak petrol şirketlerinin hızla millileştirilmesi, OPEC (Organization of Petroleum Exporting Countries, Petrol ihraç Eden Ülkeler)'in kurulması, küresel ölçekli petrol şirketlerinin ön plana çıkması, 1970'li yıllarda yaşanan petrol krizi, SSCB'nin dağılması, Körfez Savaşı, 11 Eylül Saldırıları, Irak ve Afganistan Operasyonları, Putin döneminin Rusya'da ve Ahmedinecad döneminin İran'da etkin olması, Gürcistan ve Ukrayna'da yaşanan Rusya müdahaleleri, Sudan'ın bölünmesi ve Arap Uyanışı gibi olaylar, son 100 yıl içerisinde enerji diplomasisine yön veren önemli gelişmeleri oluşturmaktadır.

Enerji diplomasisi açısından ele alındığında, para ve güç kaynağı şeklinde algılanarak adeta bir silah gibi kullanılan enerji kaynaklarına ilişkin asıl sorun, sınırlı kaynakların artan tüketim karşısında hangi güç merkezleri tarafından kontrol altında tutulacağı ve bunların hangi ülke toprakları üzerinden uluslararası piyasaya arz edileceğidir.

Enerji diplomasisine yön veren temel güçlerden biri de, çok uluslu petrol şirketleridir (Tablo 1). Bu şirketler çoğunlukla ABD, Rusya, İngiltere, Çin ve Japonya kökenlidir. Bağlı oldukları devletler tarafından yönlendirilen çok uluslu petrol şirketleri, her zaman için, enerji diplomasisinde devletlerden sonraki en önemli aktörlerinden biri olmayı başarmışlardır.

Çin, Hindistan, ABD ve Türkiye gibi ülkelerde yaşanan enerji ihtiyacındaki artış, bölgesel ve küresel enerji senaryolarını gündeme getirmektedir. Senaryolarda Çin ve Hindistan ön plana çıkmaktadır. Özellikle bu iki ülkenin artan enerji talebi, uluslararası enerji arz - talep dengesini bozmakta, bu durum enerji fiyatlarında dalgalanmalara ve hızlı artışlara neden olmaktadır. Çin ve Hindistan, artan enerji taleplerini karşılama konusunda Arap Yarımadası ve Orta Asya Devletleri ile olan ilişkilere entegre olmuşlar ve böylece yaşanan enerji mücadelesine $A B D$ ve Rusya'nın dışında yeni güçlerin eklenmesine yol açmıştır.

Tablo 1: Küresel petrol şirketleri ve menşeleri (ABD Enerji Bakanlığı, 2008).

Table 1: The origin of the global oil companies (US Department of Energy, 2008).

\begin{tabular}{|l|l|}
\hline Devlet & Petrol Şirketleri \\
\hline ABD & $\begin{array}{l}\text { Exxon Mobil, Arco, Chevron, Onocal, } \\
\text { Conoco, Texaco, Pennzoil, Bridas } \\
\text { (*En büyük ilk 7 şirketi) }\end{array}$ \\
\hline Rusya & $\begin{array}{l}\text { Lukoil, Gazprom, Yukos, Transneft, } \\
\text { Rosneft, Sidanko, Slavneft }\end{array}$ \\
\hline Çin & Cnpc, Cnooc, Sinopec \\
\hline Japonya & Jit Oil, Mitsui, Itochu \\
\hline İngiltere & British Petrol, British Gas \\
\hline Almanya & Deminex \\
\hline Fransa & Total Final Elf \\
\hline İtalya & Agip, Eni \\
\hline Kanada & Alberta \\
\hline Norveç & Statoil \\
\hline Suudi Arabistan & Delta Oil, Ningharco \\
\hline Azerbaycan & Socar \\
\hline Türkmenistan & Türkmenneftegaz \\
\hline Özbekistan & Uzbekneftegaz \\
\hline Kazakistan & Kazakistanaspislf \\
\hline Endonezya & Pertamina \\
\hline Türkiye & Türk Petrol Anonim Ortaklığı \\
\hline ABD - İngiltere & BP Amaco \\
\hline İngiltere - Hollanda & Shell Royal Dach \\
\hline
\end{tabular}

Enerji diplomasisi açısından sorun sadece enerji temini değil aynı zamanda enerji boru hatlarının güvenlik içerisinde nereden geçeceğidir. Azerbaycan ve Kazakistan petrolleri ile Rusya ve Türkmenistan doğalgazının arzında enerji koridoru olma durumu, Türkiye'yi çok etkilemektedir. Ama bir taraftan Rusya bütçe gelirlerinin büyük kısmının petrol ve doğalgazdan sağlanması diğer taraftan Orta Asya devletleri üzerinde Rusya nüfuzunun devam etmesi, Türkiye'nin enerji koridoru olma konusundaki isteğini sıkıntıya sokmaktadır.

Enerji temini konusunda Türkiye açısından takip edilmesi ve önemsenmesi gereken diğer bir husus, petrol üretiminin gittikçe üst seviyeye ulaşmasıdır. Bu durum bir gün, petrol ve doğalgaz üretiminde azalmanın başlamasına, enerjiye ulaşmada sıkıntıya ve enerji fiyatlarında beklenmedik artışlara neden olacaktır. Bu nedenlerden dolayı Türkiye, 
yenilenebilir enerji kaynaklarını devreye sokarak petrol ve doğalgaza olan bağımlılığını azaltmaya çalışmalı, mevcut enerji kaynaklarına ilişkin istatistiki verilerini güncellemeli, yeni kaynak ve rezervleri tespit ederek hizmete sunmalı, üretim ve arz teknolojisini geliştirmeli ve yatırımcılara teşvikte bulunmalıdır. 2013 yılı itibari ile Türkiye'nin dışa bağımlılığının petrolde \% 93 ve doğalgazda \% 97 olduğu göz önüne alındığında, durumun vahameti ortaya çıkmaktadır.

Enerjinin ne denli önemli olduğunu 3 cümlede toplayabiliriz. illki, siyasi coğrafya ve jeopolitiğin temel unsurlarından birini, enerjinin oluşturmasıdır. Çünkü enerji, ekonomik servet ve siyasi güç demektir. Bu nedenle enerji hem güç alınan hem de güç yansıtılan ve işbirliği içerisinde olunması gereken stratejik bir unsurdur. İkincisi; ekonomik kalkınma ve nüfuz üzerinde doğrudan etkilidir. Üçüncüsü ise enerji, sürdürülebilir kalkınma ve siyasi istikrarın anahtarlarından biridir.

Günümüzde enerji diplomasisi açısından yeryüzünde üç önemli saha ön plana çıkmaktadır: Orta Doğu, Kuzey Buz Denizi çevresi ve Kafkasya. Kafkasya denilince kökten dincilik, etnik çatışmalar, suç örgütleri ve ekonomik sıkıntılar akla gelmektedir. Oysaki Kafkasya'nın kalbini kapsayan asıl sorunu, Hazar Havzası oluşturmaktadır. Petrol ve doğal gaz piyasalarının küreselleştiği günümüzde Hazar Havzası, sahip olduğu enerji kaynakları ile enerji diplomasisi açısından önemli bir oyun sahnesine dönüşmüştür (Tablo 2, Tablo 3).

Tablo 2: Hazar havzası petrol rezervleri (ABD Enerji Bakanlığı, 2008).

Table 2: Oil reserves of the Caspian basin (US Department of Energy, 2008).

\begin{tabular}{|l|c|c|c|}
\hline Hazar Havzası Petrol Rezervleri \\
\hline Devlet & $\begin{array}{c}\text { Mevcut } \\
\text { Rezerv } \\
\text { (ortalama } \\
\text { milyar varil) }\end{array}$ & $\begin{array}{c}\text { Olası } \\
\text { Rezerv } \\
\text { (ortalama } \\
\text { milyar varil) }\end{array}$ & $\begin{array}{c}\text { Toplam } \\
\text { Rezerv } \\
\text { (milyar varil) }\end{array}$ \\
\hline Kazakistan & 15 & 85 & 100 \\
\hline Azerbaycan & 10 & 30 & 40 \\
\hline Türkmenistan & 2 & 30 & 32 \\
\hline İran & 1 & 12 & 13 \\
\hline Rusya & 1 & 5 & 6 \\
\hline Özbekistan & 1 & 1 & 2 \\
\hline Toplam & 30 & 163 & 193 \\
\hline
\end{tabular}

Tablo 3: Hazar havzası doğal gaz rezervleri.

Table 3: Natural gas reserves of the Caspian basin.

\begin{tabular}{|l|c|c|c|}
\hline \multicolumn{4}{|c|}{ Hazar Havzası Doğalgaz Rezervleri } \\
\hline Devlet & $\begin{array}{c}\text { Mevcut } \\
\text { Rezerv } \\
\text { (ortalama } \\
\text { milyar } \mathbf{~ m}^{\mathbf{3}} \text { ) }\end{array}$ & $\begin{array}{c}\text { Olası Rezerv } \\
\text { (ortalama } \\
\text { milyar } \mathbf{~}^{\mathbf{3}} \text { ) }\end{array}$ & $\begin{array}{c}\text { Toplam } \\
\text { rezerv } \\
\text { (milyar } \mathbf{~ m}^{\mathbf{3}} \text { ) }\end{array}$ \\
\hline Türkmenistan & 140 & 160 & 300 \\
\hline Kazakistan & 75 & 95 & 170 \\
\hline Özbekistan & 80 & 40 & 120 \\
\hline Azerbaycan & 10 & 40 & 50 \\
\hline İran & - & 10 & 10 \\
\hline Toplam & 305 & 345 & 650 \\
\hline
\end{tabular}

SSCB döneminde bölgede enerji kaynaklarının dünya piyasasına arzında sorun yaşanmamaktaydı. Çünkü tüm bölge kendisine aitti. Ancak SSCB sonrası dönemde ortaya çıkan Kafkas ülkelerinin çoğunun doğrudan deniz ile bağlantılarının olmaması ve bu durumun erişim maliyetlerini artırması nedeniyle bölge ülkeleri açısından en önemli sorun, çıkarılan petrol ve doğalgazın uluslararası piyasaya hangi ülkeler üzerinden arz edileceği olmuştur. Kafkas ülkeleri, enerji kaynaklarını komşu ülkelerden geçen boru hatlarıyla nakletmek zorundadırlar. SSCB döneminde çıkartılan petrol ve doğalgaz, boru hatları ile ya Karadeniz ya da Doğu Avrupa üzerinden Batı'ya aktarılıyordu. 1991'den sonra ise $A B D, A B$, Çin, Japonya gibi yeni aktörlerin bölgeye müdahil olmaları ve dolayısıyla bölge üzerinde yeni çıkarların oluşması hem bölge ülkeleri arasındaki hem de dış güçlerle bu bölge devletleri arasındaki ilişkilere farklı bir boyut kazandırdı (Kahraman, 2008). Böylece Hazar'ın statü ve paylaşım sorunu, uluslararası bir soruna dönüştü.

Hazar'ın statü ve paylaşım sorunu, SSCB sonrasında kıyıdaş ülke sayısının 5'e yükselmesi ile gündemde yer almaya başlamıştır. Ancak yıllardır yapılan görüşmelere ve imzalanan anlaşmalara rağmen Hazarın statü sorunu halen çözülmüş değildir. Çünkü her kıyıdaş ülke, çıkarları yönünde bir dış politika izlemektedir.

\section{Hazar Havzası'nın Coğrafi ve Tarihi Özellikleri}

Hazar Gölü, adını Hazar Türklerinden alan dünyanın en büyük tuzlu su gölüdür. Tarih boyunca Caspium Mare, Hvalınskoye More, Daryayı Şomal, Daryayı Khazar, Kassi, Si Hay, Bakı, Kaspiy, Mazandaran, Bahr-ül Hazar, Khazar, Girkanya, Khvalynskoe More, Khvaly Denizi, Hvalan, Gilan, Kaspi, Caspian gibi isimler ile anılmıştır (Öğütçü, 1995; Meftun, 2004; Gayıbov, 2005; Djalili ve Kellner, 2009). Okyanus ve denizler ile nehir / kanal şebekesi dışında herhangi bir doğal bağlantısı yoktur. Don ve Volga nehirlerindeki kanallar ile Karadeniz ve Baltık Denizi'ne bağlantısı vardır (Çolakoğlu, 1998).

Hazar Gölü yaklaşık 500 milyon yıl önce Kambrien döneminde oluşan ve şimdiki Marmara, Karadeniz, Azak Denizi, Hazar Gölü ve Aral Gölü'nün yer aldığı sahayı kaplayan bir iç deniz konumundaki Sarmatya Denizi'nin süreç içerisinde çeşitli parçalara bölünmesi sonucu ortaya çıkmıştır. Kabaca $36^{\circ}-47^{\circ}$ kuzey paralelleri ile $45^{\circ}-54^{\circ}$ doğu meridyenleri arasında yer almaktadır. Batıda Azerbaycan, kuzeybatıda Rusya, kuzey ve kuzey doğuda Kazakistan, doğuda Türkmenistan ve güneyde İran ile çevrilidir.

Hazar Gölü'nün toplam yüzölçümü yaklaşık 375.000 km² olup toplam kıyı uzunluğu 7000 km civarındadır. Hazar Gölü'ne kıyıdaş olan 5 ülke vardır. Bu ülkeler ve Hazar Gölü'ndeki kıyı uzunlukları; Kazakistan (2320 km), Rusya (1930 km), Türkmenistan (1200 km), Azerbaycan (825 km) ve İran $(740 \mathrm{~km}$ )'dır (Fotoğraf 1). Gölün toplam su hacmi yaklaşık 75.000 km³'tür. K - G uzunluğu yaklaşık $1200 \mathrm{~km}$ ve $B$ - D genişliği 430 km'dir. Ortalama genişliği $310 \mathrm{~km}$ olan gölün en geniş yeri $510 \mathrm{~km}$ iken en dar yeri ise Apşeron Burnu - Tarta arasında 200 km'dir. Ortalama derinliği 180 m 
olan gölün en derin noktası, Azerbaycan'a ait Lenkeran bölgesinde yaklaşık 1100 m'dir. En sığ yeri ise kuzeyde Volga (İdil) Nehri'nin denize döküldüğü sahada yaklaşık $5 \mathrm{~m}$ 'dir. Gölün rakımı ise -28 m'dir (Onan, 2006; Djalili ve Kellner, 2009). Hazar Denizi'ne dökülen belli başlı ırmaklar kuzeyde Volga (İdil), Ural ve Emba; doğuda Etre; batıda Kuma, Terek, Sulak, Samur, Kur, Astara Çayı; güneyde ise Kızı Ören ırmağının Gılan ve Sefidrüd kollarıdır. Hazar'ın en önemli beslenme kaynağı ise, Volga'dır. Hazar Denizi'nde çok sayıda ada ve 1 tane yarımada (Abşeron) vardır.

Yaklaşık 375.000 km²’lik yüzölçümüyle Hazar, dünyanın dört tarafı çevrili en büyük tuzlu su kütlesine sahiptir. Hazar'ın yüzeyi Büyük Göllerin yüzeyinin iki katına erişmekte, Umman ve İran körfezlerinin yüzölçümleri toplamını geçmekte ve hemen hemen Meksika Körfezinin yüzölçümüne (464 bin $\mathrm{km}^{2}$ ) ulaşmaktadır (Romano, akt: Poyraz, 2010).

Tarihi çok eski çağlara kadar inen Hazar bölgesi süreç içerisinde; Akhun Devleti, Sasani Devleti, Hazar Devleti, Moğol İmparatorluğu, Selçuklu Devleti, Bizans İmparatorluğu, Osmanlı Devleti, Rusya ve İran gibi çok sayıda devletin kontrolü altında kalmıştır.

Bölgenin önemi zengin petrol ve doğalgaz rezervlerine sahip olmasından ileri gelmektedir. Orta Asya ve Kafkasya bölgesindeki SSCB Cumhuriyetleri bağımsızlıklarını kazandıktan sonra kalkınma hamlelerini gerçekleştirmek için doğal kaynakları etkili bir şekilde kullanmaya çalışmışlardır. Hazar Havzası'nda bulunan doğalgaz ve petrol yatakları bu yeni kurulan ülkelerin hem kalkınmalarını sağlamada hem de dış ülkelere olan bağımlılıklarının azalmasında önemli bir faktör olmuştur (Aydın, 2012).

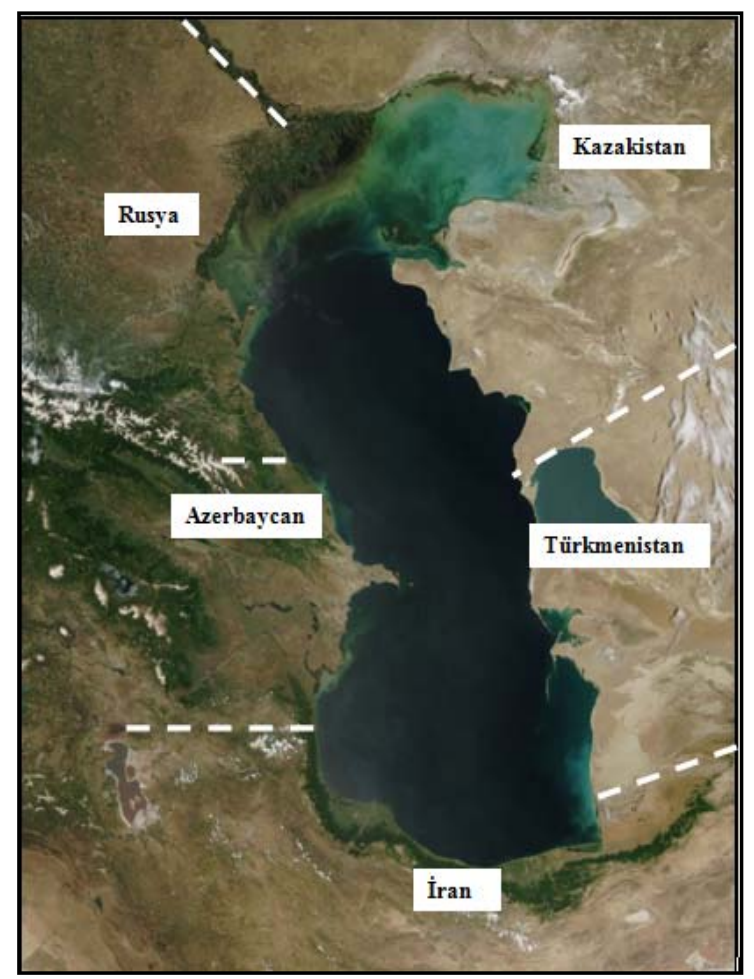

Fotoğraf 1: Hazar Gölü ve kıyıdaş ülkeler.

Photo 1: Caspian Lake and riparian countries.

\section{Hazar Havzası'nın Statü ve Paylaşım Sorunu}

Enerji diplomasisi açısından bölgedeki en önemli sorun, Hazar'ın hukuki statüsü ve paylaşımı ile ilgilidir. SSCB'nin dağılmasından sonra oluşan yeni jeopolitik koşullarda Hazar'ın hukuki statüsünün belirsizliği ve beş kıyıdaş devletin bulunması, Hazar'ı uluslararası potansiyel anlaşmazlıklarının kaynağı haline getirmiştir. Hala geçerli olan SSCB anlaşmaları, Hazar'a kıyısı olan SSCB'ye bağlı devletleri bir çıkmaza sürüklemiştir (Sekenova, 2006).

Hazar Havzası'nın statüsü ile ilgili ilk anlaşmalar, Çarlık Rusyası ile İran arasında yapılmıştır. Bunlardan ilki 23 Eylül 1723 Petersburg Anlaşması'dır. Bu anlaşma ile Hazar'da sadece Rus donanmasının bulunmasına karar verilmiştir. 13 Şubat 1729 Reşt Anlaşması ile Hazar Gölü’ne dökülen Kür ve Araz nehirlerinde serbest gemicilik yapılmasına karar verilmiştir. 12 Ekim 1813 Gülistan Anlaşması'nın 5. bölümüne göre, İran Deniz Kuvvetlerinin Hazar'da kullanılması yasaklanmıştır. 10 Şubat 1828 Türkmençayı (Turkomanchia) Anlaşması'nda, Rusya ve İran arasındaki kara sınırının Hazar'da sona ereceği kararlaştırılmıştır. Böylece Hazar, sınır tespitinde ilk kez önemli rol oynamıştır. Ayrıca Anlaşma'nın 8. maddesi ile İran'a bazı kısıtlamalar getirilmiştir. Buna göre Hazar'da sadece Rusya savaş gemisinin bulunmasına karar verilmiştir. 1881 Tarihli Anlaşma ile de Astara - Hasan Gulu sınır hattı belirlenerek (Şekil 1), Hazar'ın esas kısmının (\% 87'sinin) Rusya'ya ait olduğu kararı alınmıştır (Baykal, 1995; Uslu, 2006; Romano: akt: Poyraz, 2010).

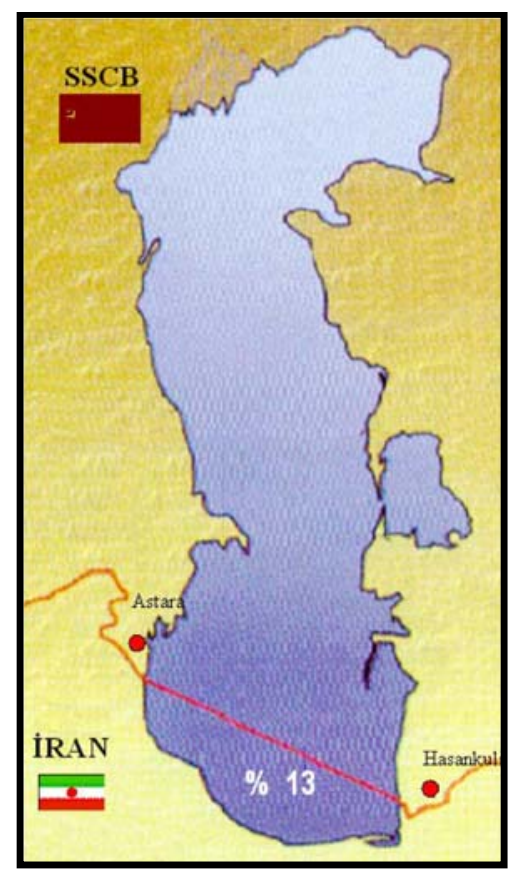

Şekil 1: İran'ın payı, 1881 tarihli anlaşma.

Figure 1: Iran's share, 1881 agreement.

Sovyet Rusyası döneminde ise İran'la 3 anlaşma imzalanmıştır. 26 Şubat 1921 işbirliği ve Dostluk Anlaşması ile Sovyet Rusyası, Çarlık Rusyası ile İran arasında imzalanan tüm anlaşmaları geçersiz kabul etmiş ve İran'ın da Hazar'da donanma bulundurmasına imkân sağlamıştır. 27 Ağustos 1935 Yerleşme ve Ticaret Anlaşması sonucunda Hazar, SSCB 
- İran sınırı olarak kabul edilmiştir. 25 Mart 1940 Ticaret ve Deniz Seyrüsefer Anlaşması ile kıyı çizgisinden itibaren 10 millik saha içerisinde balıkçılık yapan gemilerin devlet bayraklarını taşımasına karar verilmiştir. Dikkat edilecek olunursa yapılan anlaşmalar çoğunlukla Hazar'da deniz ulaşımı ve balıkçıı̆̆a ilişkin konuları içermekte buna karşın deniz sınırlarının çizilmesi ve kıta sahanlığında bulunan enerji kaynaklarının paylaşımına ilişkin bir düzenleme getirmemiştir. Çünkü anlaşmalar ile sadece Hazar Gölü'nün yüzeyi ve dibinin ortak kullanımı öngörülmüştü. Ancak taraflar resmen olmasa da uygulamada Astara - Hasan Gulu hattını sınır kabul etmişlerdir. Bu sınıra göre Hazar Gölü’nün \% 13'ü İran'a, \% 87'i ise SSCB'ye kalmıştır. SSCB 1970 yılında kendisine ait olan kısmı Rusya - Azerbaycan - Kazakistan Türkmenistan arasında paylaştırmıştır. Söz konusu paylaşım SSCB dağılana kadar önemli bir soruna neden olmamıştır (Karabayram, 2011). Çünkü bölgedeki petrol ve doğalgaz üretimi sadece SSCB merkez yönetiminin elindeydi. Ancak SSCB'nin dağılması, Hazar'a kıyıdaş ülke sayısının artması, Hazar enerji kaynaklarının uluslararası pazarlara arzı, enerji kaynaklarına ait boru hatlarının yeni kurulan devletlerin ülke topraklarında kalması gibi gelişmeler, Hazar'ın statü ve paylaşım sorununu ortaya çıkarmıştır. Söz konusu sorun günümüzde bölgenin küresel aktörlerin mücadele sahası olarak görülmesine ve yaşananların "Yeni Büyük Oyun - Boru Hatları Savaşı" adlandırımasına neden olmuştur.

SSCB'nin dağılmasından sonra ise 1994 Azerbaycan-FOCC (Yabancı Petrol Şirketleri Konsorsiyumu), 1998 KazakistanRusya, 2001 Rusya-iran, 2001 Rusya-Azerbaycan, 2001 Azerbaycan-Kazakistan Anlaşmaları ve 2003 RusyaKazakistan-Azerbaycan Anlaşması'ndan sonra -Hazar'da beş taraflı bir anlaşmaya gidilememiş olsa da- Rusya, Kazakistan ve Azerbaycan'dan oluşan kuzey kıyıdaşları aralarında kısmen bir uzlaşmaya varılmıştır. Türkmenistan ve İran'dan oluşan güney kıyıdaşları arasında ise henüz böyle bir durum yoktur. Hazar'ın hukuksal statü sorununu uluslararası gündeme taşıyan olay ise, 1994 yılında Azerbaycan - FOCC arasında imzalanan ve Yüzyılın Anlaşması olarak bilinen anlaşmaya Rusya ve İran'ın tepki göstermesi olmuştur.

Hazar'ın statüsü ilgili hukuksal sıkıntı, bir deniz olarak mı yoksa bir göl olarak mı kabul edileceğidir. Çünkü 1982 Birleşmiş Milletler Deniz Hukuku Sözleşmesi'ne göre her iki kabullenme farklı sonuçlar ortaya çıkarmaktadır. 1982 BM Deniz Hukuku Sözleşmesi'nin (BMDHS) Kısım 9'daki 122. Maddesi: "Kapalı veya yarı-kapalı deniz; iki veya daha fazla devlet tarafından etrafı çevrili diğer bir denize veya okyanusa dar bir geçitle bağlı bulunan veyahut da bütünüyle veya büyük bir bölümü ile iki veya daha çok devletin karasularından ve münhasır ekonomik bölgelerinden oluşan bir körfez, bir deniz havzası veya bir deniz anlamına gelir." ifadesini içermektedir.

* Eğer Hazar bir deniz kabul edilirse (madde 122-123124); her kıyıdaş ülke eşit pay alacak ve ilaveten kıyıdaş ülkeler kara sularının dışında deniz yüzeyinde, deniz içerisinde, deniz dibinde ve dibin alt katmanlarında arama ve işletme haklarını içeren 20 deniz mili mesafede bir münhasır ekonomik sahaya (BMDHS madde 57'ye göre 200 mili geçemez) sahip olacaklardır. Bu mesafenin dışında kalan 40 deniz millik kısım ise uluslar arası deniz kabul edilecektir (Şekil 2). İran ve Türkmenistan bu paylaşımı kabul ederken Rusya, Kazakistan ve Azerbaycan karşı çıkmaktadır. Çünkü bu tür bir paylaşımda, Hazar'a olan kıyı uzunlukları göz alınmayacağından dolayı, daha fazla kıyı uzunluğuna sahip bu 3 devlet zarara uğramaktadır. Böylesine bir paylaşımdan en karlı çıkacak olan devlet, İran'dır. İran eşit paylaşımda Araz - Alov - Şark petrol sahasını kendi sınırları içerine almış olacaktır. Rusya'nın Hazar'ın deniz olmasına sürekli olarak itirazı vardır. Eğer Rusya Hazar'ı deniz olarak kabul ederse, Don-Volga ve Volga-Baltık kanallarında uluslararası suyolu rejimini uygulamak zorunda kalacaktır. $\mathrm{Bu}$ durumda Hazar'a kıyısı olan diğer devletler bu kanallardan transit geçiş yapma hakkına sahip olabileceklerdir (Uslu, 2006 ; Dion, 1998).

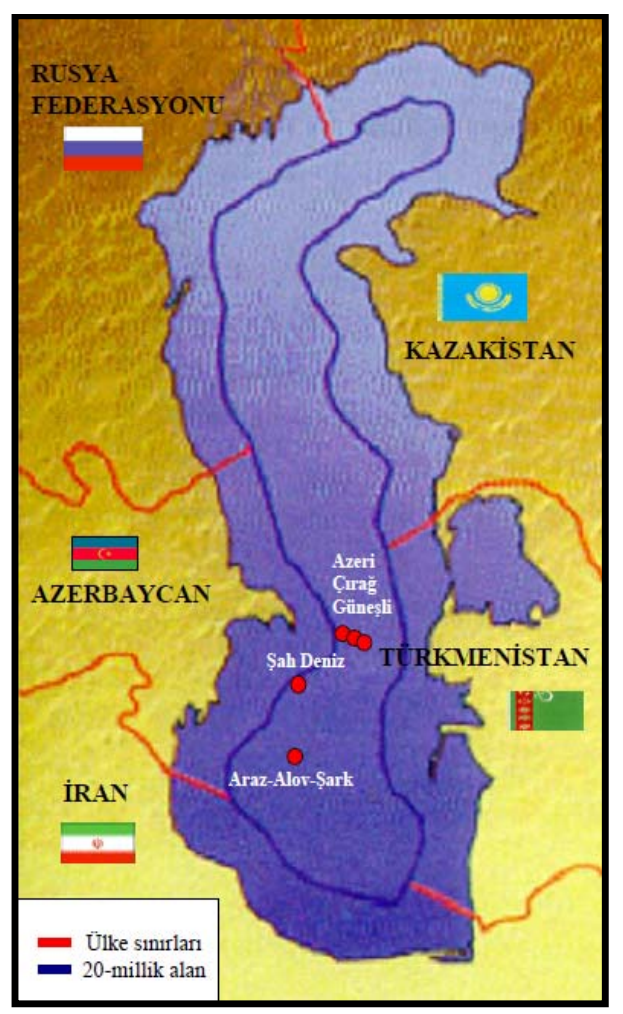

Şekil 2: Deniz kabulüne göre paylaşım

Figure 2: Sharing acceptence by the Sea.

* Eğer Hazar bir göl kabul edilirse iki şekilde bir paylaşım esası ortaya çıkmaktadır. Her iki paylaşım de facto olarak görülebilir. Çünkü sınır gölleri için kabul edilmiş uluslararası sınır belirleme yöntemi yoktur (Gökçe, 2008). Bu esaslardan ilkine göre, kıyıdaş ülkeler Hazar kıyısındaki kıyı uzunluklarına göre pay alacak ve ilaveten kıyı çizgisinden itibaren 20 deniz mili mesafede bir sahaya sahip olacaklardır. Bu durumda 20 deniz mili mesafenin dışında kalan sahanın (su yüzeyinin) -ortak egemenlik/ mülkiyet (condominium) sınırlandırılması nedeniyle- arama ve işletme hakları kıyıdaş ülkelerin oluşturacağı ortak bir yönetime verilecek ve kararlar oy birliğe ile alınacaktır. Orta egemenlik ilkesinin temelini Hazar üzerinde tüm kıyıdaş 
devletlerin ortak mülkiyet hakkına sahip olduğu düşüncesi oluşturmaktadır. Bu duruma tek örnek Peru ve Bolivya arasında Titicaca Gölü'nün paylaşımdır (Abilov, 2013). Böylesine bir paylaşımda Kazakistan \%29,6, Azerbaycan $\% 19,5$, Rusya $\% 18,7$, Türkmenistan $\% 18,4$ ve İran ise $\% 13,8$ pay alacaktır (Nugman, 1998).

Diğer esasa göre ise (BMDHS, madde 15), bütün kıyı devletlerinin sahillerinden eşit uzaklıkta çizilen merkez (orta) hattıyla ve bu merkez hattı üzerindeki kara sınırlarının son noktasından çizilen bir dikey hatla ulusal sektörlere bölünebilir. Sonra da devletlerin sınırları, göl üzerindeki sınır çizgisi boyunca devletlerin topraklarına ilgili bölümlerin eklenmesiyle geçer. Devletlerin bu bölgeler üzerindeki doğal kaynakları çıkarma hakları sınır çizgisine kadar olan göl sularını kapsamaktadır. Diğer bir ifade ile her devlet kendisine ait bölge içerisindeki sahaya sahip olmaktadır. Sınır gölünün bu tür bölünmesi $A B D$ ve Kanada arasında Büyük Göller, Fransa ve İsviçre arasında Geneva Gölü, Almanya - Avusturya ve İsviçre arasında Konstanz Gölü, Malawi ve Mozambik arasında Mozambik Gölü, Kenya Tanzanya ve Uganda arasında Victoria Gölü, Nijer ve Nijerya arasında Çad Gölü ile gerçekleşmiştir (Gökçe, 2008 ; İşcan, 2010). Göl yatağından orta hat (median line, equidistance line) esasına göre yararlanmayı öngören bu paylaşımı Kazakistan, Rusya ve Azerbaycan kabul etmekte buna karşın güney kıyıdaşlar olan İran ve Türkmenistan karşı çıkmaktadır (Uslu, 2006). Çünkü böylesine bir paylaşımda kıyı çizgisi uzunluğu fazla olan Rusya, Kazakistan ve Azerbaycan fazla pay alacaklardır (Şekil 3). Bu da İran ve Türkmenistan tarafından adilane paylaşım olarak kabul edilmemektedir. Böylece Hazar'ın kuzey ve güneyinde iki farklı görüş ortaya çıkmış görünmektedir. Ancak bu esasta, Türkmenistan ve Azerbaycan arasındaki petrol ve doğal gaz açısından zengin Güneşli - Çırağ - Azeri sahalarının paylaşımı önemli bir sorundur. Her iki devlet bu sahayı kendi kontrolünde tutmak istemektedir. Şu anda Azerbaycan kontrolünde olan saha, Azerbaycan International Oil Trading Company (AIOC) tarafından işletilmektedir.

Sonuç olarak günümüzde, Rusya, Azerbaycan ve Kazakistan ile İran ve Türkmenistan arasında bir KuzeyGüney anlaşmazlığı mevcuttur. Hazar’ın statüsü ne olursa olsun, Hazar üzerindeki hak ve yükümlülükler rejimi, kıyıdaş devletlerin anlaşmaları sonucu ortaya çıkacaktır (Terzioğlu, 2008). ABD, Hazar'ın hukuki statüsünün acilen çözülmesini istiyor ve bu çözüm yolunda Azerbaycan'ın tutumunu açıkça desteklemektedir. Çünkü Hazar'ın sektörsel olarak Azerbaycan'ın istediği tarzda bölünmesi, ABD'nin bölgedeki ekonomik çıkarlarıyla örtüşmektedir.

Hazar'a kıyıdaş devletlerin statü ve paylaşım ile ilgili tutumunu özetlemek gerekirse;

1. Azerbaycan: Hazar'ın hem tabanının hem de su yüzeyinin bölünmesini ve her bir kıyıdaş devletin kendi sektörünü denetim altına tutmasını savunmaktadır.

2. Rusya: Hazarın sadece tabanının bölünmesini ama su yüzeyinin ortak kullanıma verilmesini istemektedir.

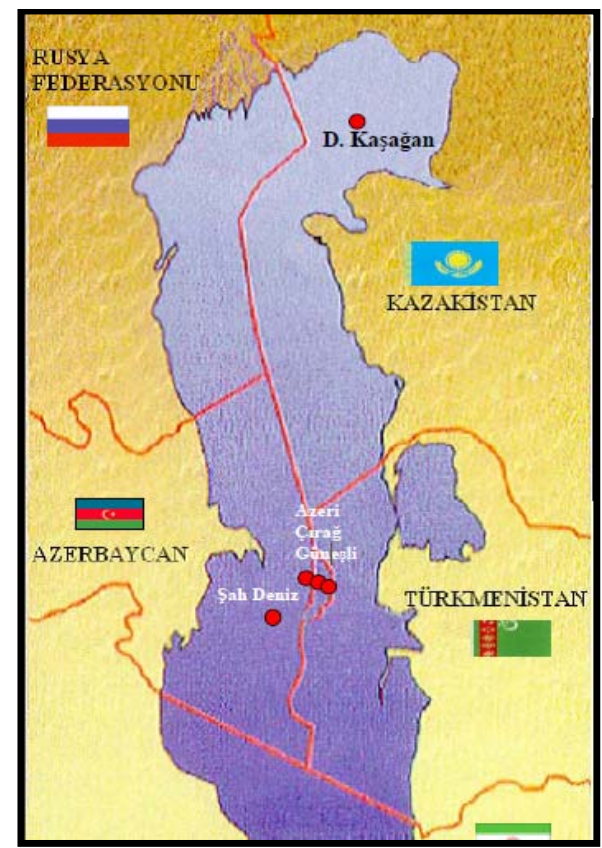

Şekil 3: Hazar'ın Orta Hat Esasına Göre Paylaşımı (Kahraman, 2008).

Figure 3: According to the midline of the accepte the Caspian sharing (Kahraman, 2008).

Rusya, uluslararası hukuk ve çevresel kaygılarını öne sürerek Hazar'ın ortak mülkiyetini ve kullanımını savunurken, aslında eski SSCB sınırlarındaki nüfuzunu korumayı ve stratejik üstünlüğünü kaybetmemeyi hesaplamaktadır. Moskova'nın ulaşmak istediği diğer bir amaç ise, Hazar'ı hukuken belirsiz bir konumda tutarak, kendi aleyhine olarak değerlendirdiği Batı yatırımının bölgeye girişini engellemek ve bölgenin enerji arz tekelini Rus şirketleri vasıtası ile kendi elinde tutmaktır (Gökçe, 2008). Genel olarak ele alındığında Rusya Hazar konusunda çözümsüzlükten yanadır. Çünkü sorunun çözümü sonrası oluşacak her yeni gelişim (yeni petrol hatları gibi) Rusya açısından olumsuzluğa neden olacaktır.

3. Kazakistan: Hazarın sadece tabanının her bir kıyıdaş devlet tarafından denetim altında tutulmasını buna karşın su yüzeyinin ise ortak kullanımına verilmesini istemektedir.

4. Türkmenistan: Hazarın hem tabanının hem de su yüzeyinin bölünmesini ve her bir kıyıdaş devletin kendi sektörünü denetim altına tutmasını istemektedir. Bakıldığında Azerbaycan ile aynı görüşte olduğu görülmektedir. Ancak bu konuda bir şart ileri sürmektedir. Güneşli - Çırağ ve Azeri'nin kendisinde kalmasını istemektedir. Azerbaycan ise bunu kabul etmemektedir.

5. İran: Hazarda her bir kıyıdaş devletin \%20 oranında eşit paya sahip olmasını istemektedir. Bu durumda İran, Araz Alov - Şark petrol sahalarını sınırlarına katmış olacaktır.

Hazar'ın mevcut hukuki rejimi, ne deniz hukuku alanıyla ne de uluslararası göller hukuku alanıyla tam olarak örtüşmektedir. Dahası, emredici normlara da bağlı değildir. Kıyıdaş devletler, aralarındaki açık veya üstü kapalı uzlaşıyla her zaman değişiklik yapmakta özgürdür. Yalnızca sürdürülebilir hukuki rejim, kıyıdaş tüm devletlerin hakça 
kalkınması ve doğal kaynaklarının sürdürülebilir kullanımını sağlayan hakkaniyete uygun bir rejimdir. Böyle bir rejim, yalnızca tüm kıyıdaş devletlerarasında özgürce görüşülen bir anlaşmadan doğabilecektir (Romano, akt: Poyraz, 2010).

1930'lu yılların başında Urallarda, 1935 yılında Hazar Gölü'nde keşfedilen petrol yatakları ve 1949 yılı kasım ayında Hazar Gölü'nde petrol üretiminin başlaması, SSCB'yi kısa sürede $A B D^{\prime}$ den sonra en büyük 2. Petrol üreticisi konumuna getirmiştir (Gouliev, 1997). Günümüzde ise Hazar Havzası'nda varlığı kanıtlanmış yaklaşık 30 milyar varil petrol rezervi ve 305 milyar $\mathrm{m}^{3}$ doğalgaz bulunduğu tahmin edilmektedir. Söz konusu rakamlar sahanın jeostratejik önemini ortaya koymaktadır. Bu nedenledir ki Rusya, 5 Ekim 1994 tarihinde yayımladığı bir bildirge ile Hazar Havzası'nda yapılacak tek taraflı herhangi bir eylemi tanımayacağını ve Hazar'ın deniz statüsünde değil de kapalı bir göl durumunda olduğunu duyurmuştur (Kodaman, 2002).

\section{Hazar Havzası'ndaki Enerji Kaynaklarının Nakil Sorunu}

Hazar Havzası, petrol ve doğalgaz rezervleri açısından zengin olması nedeniyle kendisine kıyısı olan Rusya, Azerbaycan, Kazakistan, Türkmenistan ve İran'ı doğrudan, buna karşın diğer devletleri ( $A B D, A B$, Türkiye, Çin, Japonya, ...) dolaylı yoldan etkilemektedir. SSCB'nin dağılmasından sonra Hazar çevresindeki istikrarlı uyum zamanla yerini rekabet ve çatışmalara terk etmiştir. Bu durum 1992 yılından günümüze Hazar Havzası'nın kontrolü, paylaşımı ve nasıl kullanılacağı konusunda bölge devletlerini karşı karşıya getirmektedir. Rusya'nın bu sorun ile elde etmek istediği, bu konuda ortalığı karıştırarak güvensiz bir ortam yaratmak ve böylece $A B D$ ve Avrupa merkezli çok uluslu petrol şirketlerinin bölgeden çekilmesini sağlayarak tek başına etki alanını genişletmek istemesidir.

Orta Asya ve Kafkasya bölgesinde üretici durumda olan devletlerin deniz bağlantılarının olmaması, alıcı konumunda olan devletlerin bölge dışında bulunması ve uzun yıllar kullanılan Rusya hattının çok masraflı olması, bölgede yaşanan enerji kaynaklı sorunların artmasına neden olmaktadır. Bölgenin en önemli sorunu nakliye sorunudur. Orta Asya, denizlere çıkışı olmayan bir bölgedir ve bu nedenle enerji kaynaklarının nakliyesi için çok uzun boru hatlarına ihtiyaç vardır. Çıkış yollarını sağlayan ülkeler Türkiye, Rusya, İran, Afganistan, Pakistan ve Çin'dir. Üstelik boru hatlarının Afganistan ve Pakistan gibi siyasi açıdan riskli bölgelerden geçme ihtimali söz konusudur. Diğer bir sorun ise enerji kaynaklarının çıkarılması ve nakliyesi için yeterli fonun bulunamamasıdır. SSCB'nin yıkılması ile birlikte devam eden ekonomik krizin giderilememesi, petrol ve doğal gazın çıkarılması konusunda yeni teknolojilerin kullanılamaması ve yabancı yatırımcıların bölgeye olan güvenlerinin tam anlamı ile sağlanamamış olması yaşanan sorunların artmasına neden olan diğer faktörlerdendir. Bölge kaynaklarının dışa açılımı konusunda boru hatları önemli bir yer teşkil etmektedir. Türkiye konumu nedeniyle enerji zengini doğu komşu ülkeleriyle, enerjiye ihtiyacı olan Avrupa ülkeleri arasında doğal bir köprü konumundadır.
Türkiye her ne kadar enerji üreticisi olmasa da, Orta Asya ve Kafkasya'da bulunan enerji kaynaklarının boru hattı projeleriyle uluslararası piyasaya taşınmasında kilit rol oynamaktadır (Aydın, 2012). Dünyada petrol ve doğalgaz tüketiminin yaklaşık yarısının OECD ülkelerinde ve bununda yaklaşık 1/3'ünün Avrupa gerçekleştiği göz önüne alındığında, Batıya açılan enerji arz yollarının önemi ortaya çıkmaktadır. Bu konuda özellikle Azerbaycan arz konusunda, Gürcistan ve Türkiye ise güzergâh konusunda ön plana çıkmaktadır.

Hazar petrol üretimlerini Basra Körfezi üzerinden akıtmak, $A B$ ve $A B D$ gibi tüketici ülkeleri arz çeşitliliği imkânından yoksun bırakmak anlamına gelecek ve Hazar enerji kaynaklarını tıpkı Basra Körfezi üretimleri gibi risk altına sokacaktır. Buna karşın Hazar'a kıyıdaş ülkeler için üretimin Basra Körfezi'ne aktarılması gelecekteki muhtemel Pakistan, Hindistan, Çin ve Japonya gibi Asya devletlerine yaklaşma açısından kolaylık sağlayacaktır. Fakat özellikle ABD'nin İslamcı militanlığı ve Nükleer çalışmaları nedeniyle uyguladığı İran'ı yalnızlaştırma politikası, Hazar'a kıyıdaş ülkeleri bu planları açısından zora sokmaktadır (Djalili ve Kellner, 2009).

\section{TARTIŞMA ve SONUÇ}

Hazar havzası petrol rezervleri, uluslararası petrol sahaları ile karşılaştırıldığında Kuzey Denizi Petrol rezervleri ile eşit, Orta Doğu'ya göre ise düşük miktardadır. Enerji çıkarma maliyeti bakımından ise Orta Doğu kadar düşük olmamakla beraber Kuzey Denizi petrol çıkarma maliyetlerinden daha düşüktür (Uslu, 2006).

Hazar'ın statüsüne ilişkin bir anlaşmanın yapılması Rusya'nın Avrupa'ya yönelik enerji kozunu büyük ölçüde yitirmesine neden olacaktır. Bu nedenle Moskova yönetiminin, Hazar geçişli projelere ilişkin ayrı düzenleme yapılmasını istediği de biliniyor. Rusya'nın sorununun kendi aleyhine çözümüne kolay kolay izin vermeyeceği ortadadır.

Hazar Denizi'nin statüsü konusunda kıyıdaş ülkeler anlaşmaya varırsa Türkmenistan'dan Bakü'ye Hazar Denizi'nin altından 200 kilometrelik boru hattıyla hem gaz hem de petrol gönderilmesi mümkün olacak. Böylece Türkmen gazı Nabucco'ya bağlanabilecek. Ancak, Hazar Denizi'nin statüsü saptanamadığı için Türkmenistan'dan Azerbaycan'a uzanan "Trans Hazar" boru hattı inşası mümkün görünmemektedir. Bu durum $A B$ açısından sıkıntı yaratmaktadır.

Hazar'daki paylaşım sadece enerji kaynaklarının paylaşımı açısından önemli değildir. Dünya havyar üretiminin yaklaşık \%90'ı bu denizden sağlanmaktadır. Bu durum üretici ülkeler açısından gelir anlamına gelmektedir.

Rusya, Kazakistan ve Azerbaycan, her ülkenin kıyı genişliğini esas alacak bir bölünme öneriyor. Bu durumda en fazla payı Kazakistan ve Rusya, en küçük payı ise İran alacak.

Hazar havzası enerji kaynaklarının uluslar arası piyasalara sunulması, Hazar kıyıdaş ülkelerinin enerji gelirlerinde 
Tablo 4: Hazar Havzası başlıca petrol boru tatları (www.enerjidergisi.com.tr)

Table 4: Caspian Basin major oil pipelines.

\begin{tabular}{|l|l|c|}
\hline Boru Hattı & Coğrafi Konumu & Uzunluğu ( km) \\
\hline Atrau - Samara & Hazar'dan Rusya'ya & 700 \\
\hline Hazar Boru Hattı Konsorsiyumu (CPC) & Hazar'dan Rusya'ya & 1600 \\
\hline Bakü - Grozni - Novorossisyk & Hazar'dan Rusya'ya & 1400 \\
\hline Bakü - Mahaçkale - Novorossisyk & Hazar'dan Rusya'ya & 325 \\
\hline Bakü - Supsa & Gürcistan'dan Türkiye'ye & 930 \\
\hline Bakü - Tiflis - Ceyhan (BTC) & Gürcistan'dan Türkiye'ye & 1780 \\
\hline Kaşuri - Batum & Gürcistan'dan Türkiye'ye & 70 \\
\hline Hazar Geçişli İkiz Boru Hattı & Gürcistan'dan Türkiye'ye & 600 \\
\hline Samsun - Ceyhan & Türkiye'ye & 550 \\
\hline Arnavutluk - Makedonya - Bulgaristan & Avrupa'ya & 900 \\
\hline Romanya - İtalya & Avrupa'ya & 1400 \\
\hline Çin Petrol Boru Hattı (CNCP) & Hazar'dan Çin'e & 3000 \\
\hline Kazakistan - Türkmenistan - İran & İran Üzerinden Basra'ya & 1500 \\
\hline Orta Asya Boru Hattı & Afganistan Üzerinden Pakistan'a & 1680 \\
\hline
\end{tabular}

Tablo 5: Hazar Havzası başlıca doğal gaz boru hatları (http://www.enerjidergisi.com.tr) Table 5: Caspian Basin major natural gas pipelines.

\begin{tabular}{|l|l|c|}
\hline Boru Hattı & Coğrafi Konumu & Uzunluğu ( km) \\
\hline $\begin{array}{l}\text { Bakü - Tiflis - Erzurum (BTE) } \\
\text { (Azerbaycan - Türkiye / Şahdeniz) }\end{array}$ & Hazar'dan Gürcistan ve Türkiye'ye & 230 \\
\hline Hazar Geçişli Doğalgaz Boru Hattı & Hazar'dan Türkiye'ye & 2000 \\
\hline Nabucco Projesi & Hazar'dan Türkiye ve Avrupa'ya & 3400 \\
\hline Mavi Akım & Rusya'dan Türkiye'ye & 1220 \\
\hline Türkmenistan - Çin & Hazar'dan Çin'e & 7000 \\
\hline Türkmenistan - İran & İan Üzerinden Basra'ya & 200 \\
\hline Devletabad - Serahs - Hangeran & İran Üzerinden Basra'ya & 35 \\
\hline Türkmenistan - Afganistan - Pakistan & Hazar'dan Pakistan'a & 1500 \\
\hline Güney Akım Projesi & Hazar'dan Avrupa'ya & 900 \\
\hline
\end{tabular}

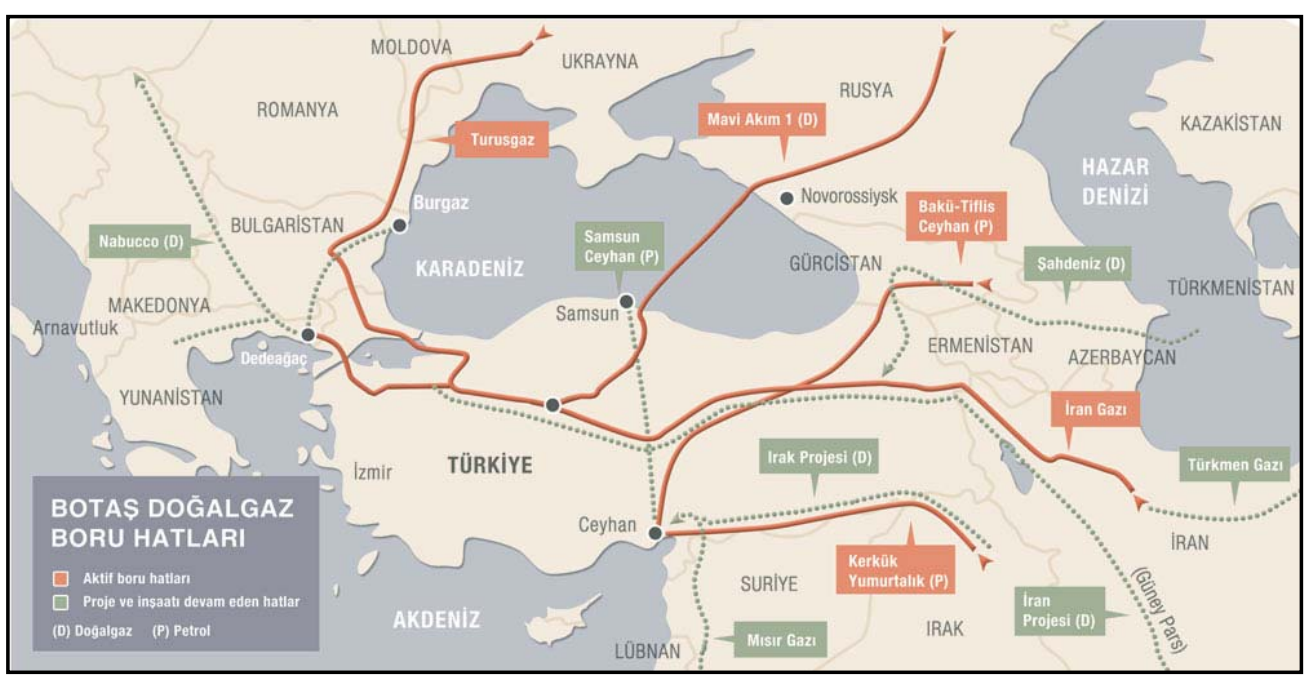

Şekil 4: Başlıca doğalgaz boru hatları (http://www.sabah.com.tr). Figure 4: Major natural gas pipelines.

önemli artışlara neden olacağı şüphesizdir. Önemli olan rezervlerin nasıl ve hangi güvenilir yollarla tüketim pazarlarına arz edileceğidir.

Enerjiye dayalı üretimden teknolojiye dayalı üretime geçildikçe enerji talebi isteğinin artacağı bilinen bir gerçektir. Bu nedenden Türkiye'nin, Orta Doğu ve Orta Asya enerji diplomasisini yoğun ve pragmatist bir şekilde sürdürmesi gerekmektedir. Ancak diplomasi tek taraflı olamayacağından Türkiye'nin diğer ülkelerde yatırımlarının ve yatırımcılarının bulunması da önemlidir. Türkiye Hazar Havzası'nda yaşanan satranç oyununda birkaç hamle ötesini görebilecek bir düşünce ve öngörüye sahip bölgesel bir güç olarak hareket etmeye özen göstermelidir. 


\section{KAYNAKLAR}

ABD Enerji Bakanlığı. (2008). Caspian Sea Region: Survey of Key Oil and Gas Statistics and Forecast.

Aydın, N. Z. (2012). "Hazar Enerji Kaynakları ve Siyaset”, KSÜ Sosyal Bilimler Dergisi, 207-224.

Abilov, S. (2013). Hazar'ın Hukuki Statüsü, Hazar Raporu, http://hasen.org.tr/content/userfiles/files/MAKALE4.pdf46-67.

Baykal, F. H. (1995). "Bölgedeki Siyasi Gelişmelerin Işığı Altında Hazar Denizi'nin Hukuki Rejiminin Değerlendirilmesi", Basım Dünyası, Ekim-Aralık, 7:55.

Çelebioğlu, T. (2005). "1990 Sonrası Türkiye-Gürcistan İlişkileri", Marmara Üniversitesi Türkiyat Araştırmaları, Enstitüsü Yayınlanmamış Yüksek Lisans Tezi, İstanbul.

Dion, R. R. (1998). "Cutting up Caspian", The World Today, 80-82.

Djalili, M. R. and Kellner, T. (2009). Yeni Orta Asya Jeopolitiği: SSCB’nin Bitiminden 11 Eylül Sonrasına, Çev: Reşat Tüzmen, İstanbul: Yaylacılık Matbaası.

Gayibov, A. (2005). “Hazar Havzası'nın Doğal Statüsü ve Bakü-Ceyhan Petrol Boru Hattı'nın Ekonomik Değerlendirilmesi”, Marmara Üniversitesi Araştırmalar Enstitüsü, İstanbul, 5-6.

Gouliev, R. (1997). Petrol ve Politika, Çev: Fatma Feran, İstanbul: Ar Matbaası, 37.

Gökçe, M. (2008). "Sovyet Sonrası Dönemde Hazar Çevresinde Yaşanan Rekabet", Uluslar arası Sosyal Araştırmalar Dergisi, 1/3: 177-209.

İşcan, i. H. (2010). “Uluslararası Enerji Güvenliği Açısından Hazar Bölgesi Enerji Ekonomisi ve Hazar Denizi'nin Paylaşım Sorunu", Sosyoekonomi, Özel Sayı, 63-92.

Kahraman, A. (2008). "Hazar Ekseninde Boru Hatları Diplomasisi", Stratejik Araştırmalar Dergisi, 12: 133144.

Karabayram, F. (2011). Güney Kafkasya Jeopolitiğinde Rusya Gerçeği, İstanbul: IQ Kültür - Sanat Yayıncılık.

Kodaman, T. (2002). “Azerbaycan Petrollerinin Uluslararası Politikadaki Önemi ve Türkiye", Ankara Üniversitesi Sosyal Bilimler Enstitüsü, Yayımlanmamış Doktora tezi, Ankara. 73.

Meftun, M. (2004). Politik ve Bölgesel Güç Hazar, İstanbul: IQ Kültür - Sanat Yayıncılık. 15.

Nugman, G. (1998). "Hazar Denizi'nin Hukuki Statüsü", Avrasya Etütleri, Sayı 13, Ankara.

Onan, S. (2006). "Yeni Global Oyun ve Hazar'ın Statüsü", http://www.turksam.org/tr/yaziyazdir, 20.08.2006.

Öğütçü, M. (1995). Eurasian Energy Prospects and Politics. Need for a Longer Term Western Strategy, Futures, V: 27, No: 1. akt: Mustafa Aydın, (2005), Küresel Politikada Orta Asya, Nobel Yayın Dağıtım, Ankara, 276-296.

Romano, P. R., (1997). La Caspienne: Un Flou Juridique, source de conflicts, Cahiers d'etudes sur la Mediterraneee orientale et le monde turco iranien, No: 23: 9-69. ; Hazar: Hukuki Bulanıklık,
Uyuşmazlıkların Kaynağı, akt: Yasin Poyraz, 2010, EÜHFD, 14(3-4): 271-289.

Sekenova, G. (2006), Hazar Denizi: Uluslararası Potansiyel ihtilaflar Bölgesi, Kafkasya Dosyası, İstanbul: Tatav Yayınları. 244.

Sevaioğlu, O. Hazar: Umut, Yaşam ve Savaşın Denizi; Kaynak: Dr. Cenk Pala, Elvira Borombaeva, BOTAŞ.

Terzioğlu, S. S. (2008). “Hazar'ın Statüsü Hakkında Kıyıdaş Devletlerin Hukuksal Görüşleri”, OAKA, 3(5): 26-47.

Uslu, K. (2006). "Hazar Bölgesi Enerji Kaynaklarının Ekonomik ve Uluslar arası Boyutu", Marmara Üniversitesi iiBF Dergisi, 21(1): 99-130.

\section{Internet Sayfası}

https://www.google.com.tr/search?q=d\%C3\%BCnyadaki+p etrol+ve+do\%C4\%9Falgaz+boru+hatlar\%C4\%B1\&espv $=210$, erişim tarihi: 02.03.2014.

http://www.sabah.com.tr/ekonomi_turkiye-irakdogalgazini-avrupaya-tasiyacak erişim tarihi: 01.10 .2013

http://www.enerjidergisi.com.tr/haber/2013/02/ enerjidearz-guvenligini-boru-hatlariyla-garantiliyor erişim tarihi: 11.10 .2013 
